SIMULATIONS OF NON-STEADY FLOW IN A GLACIAL OUTWASH AQUIFER, SOUTHERN FRANKLIN COUNTY, OHIO

By Allan C. Razem

U.S. GEOLOGICAL SURVEY

Water-Resources Investiqations Report 83-4022

Prepared in cooperation with the

CITY OF COLUMBUS, OHIO

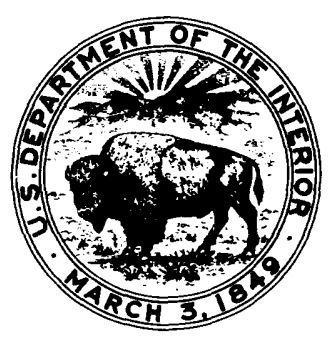

Columbus, Ohio 


\author{
UNITED STATES DEPARTMENT OF THE INTERIOR \\ JAMES G. WATT, Secretary \\ GEOLOGICAL SURVEY \\ Dallas L. Peck, Director
}

For additional information write to:

District Chief

Water Resources Division

U.S. Geological Survey

975 West Third Avenue

Columbus, Ohio 43212
Copies of this report can be purchased from:

Open-File Services Section Western Distribution Branch U.S. Geological Survey Box 25425, Federal Center Denver, Colorado 80225 (Telephone: (303) 234-5888) 


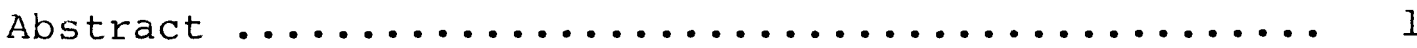

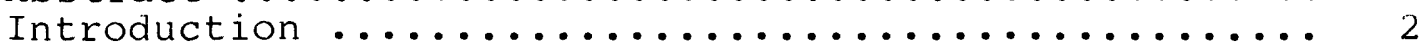

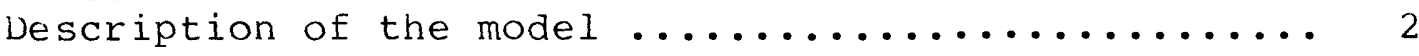

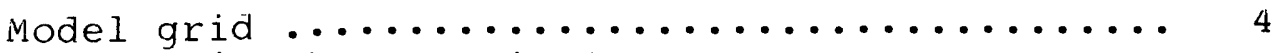

Hydrologic characteristics ............... 4

Boundary conditions and areai recharge ... 4

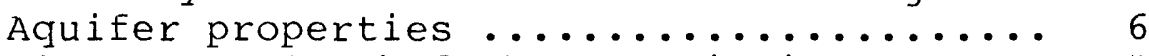

River and riverbed characteristics ...... 8

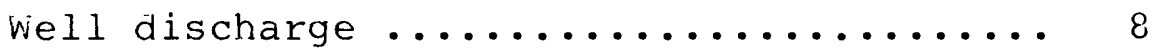

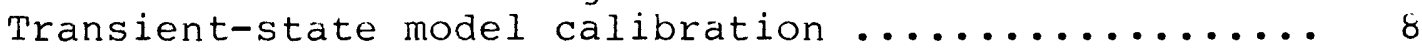

Simulated aquifer response to future pumping ....... 9 9

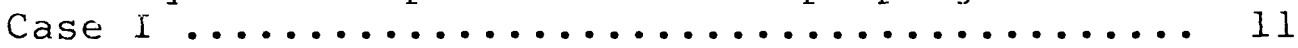

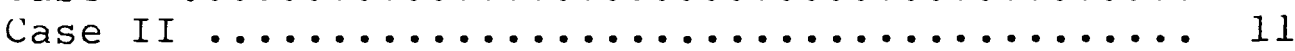

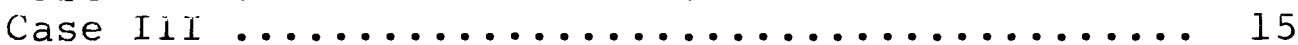

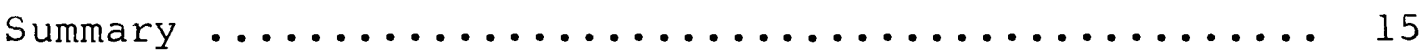

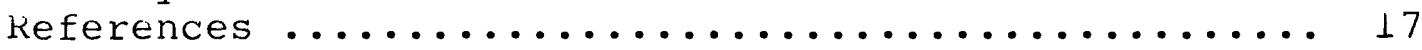

\section{LLUSTRATIONS}

Page

Figure 1. Map of study area and well locations ..... 3

2. Finite-difference grid and boundary conditions used in the modeled study

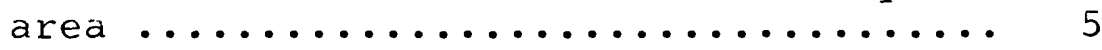

3. Comparison of observed and computed water-level changes at wells 3 and 109 from December 1977 to March 1980 ... 10

4. Map showing predicted drawdowns after combined pumping of $48.44 \mathrm{ft} 3 / \mathrm{s}$ for

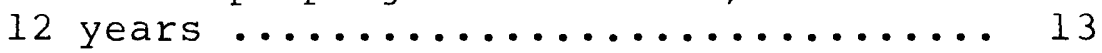

5. Map showing predicted drawdowns after combined pumping of $70.14 \mathrm{ft} 3 / \mathrm{s}$ for

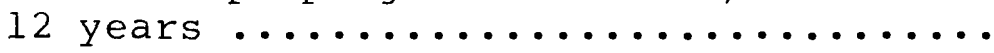

6. Map showing predicted drawdowns at time well 103 goes dry after combined pumping of $94.44 \mathrm{ft} 3 / \mathrm{s} \ldots \ldots \ldots \ldots \ldots$ 
rable 1. Hydrologic variables used in the

For the benefit of readers who prefer to use metric units, conversion factors for terms used in this report are listed below:

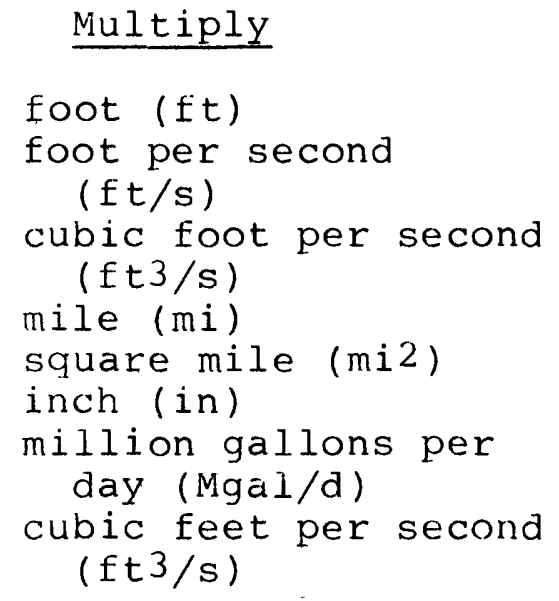

0.3048

0.02832

1.609

2.590

25.4

0.0438

0.646
To obtain

meter (m)

meter per second

$$
(\mathrm{m} / \mathrm{s})
$$

cubic meter per second $(\mathrm{m} 3 / \mathrm{s})$

kilometer $(\mathrm{km})$

square kilometer $\left(\mathrm{km}^{2}\right)$

millimeter ( $\mathrm{mm}$ )

cubic meters per second $(\mathrm{m} 3 / \mathrm{s})$

million gallons per day (Mgal/d) 


\title{
SIMULATIONS OF NON-STEADY FLOW IN A GLACIAL OUTWASH AQUIFER, SOUTHERN FRANKLIN COUNTY, OHIO
}

\author{
By Allan C. Razem
}

\section{ABSTRACT}

A two-dimensional, finite-difference model is used to simulate transient flow conditions in a qlacial outwash aquifer in southern Franklin County, Ohio. The model was calibrated by matching observed and simulated water-level changes for December 1977 through March 1980.

Drawdowns for three $d$ ifferent hypothetical pumping rates are simulated with the calibrated flow model. An increase in the combined pumping rate from the steady-state rate of 10 cubic feet per second to 48 cubic feet per second results in water-level declines of 10 to 20 feet near the area of the pumping wells. Declines of 20 to 40 feet result when the combined pumping rate is increased to 70 cubic feet per second, and a simulated pumping well goes dry when the combined pumping is increased to 94 cubic feet per second. For the first two cases, steady-flow conditions are reached after 12 years of pumping; infiltration through riverbeds accounts for 28 to 33 percent of the pumpare. 
INTRODUCTION

A qlacial outwash aquifer in part of the Scioto River basin was evaluated by the U.S. Geological Survey in cooperation with the City of Columbus, ohio. The purpose of this report is to describe the development of a transient-state digital-computer morel and the simulated water-level resulting from anticipated withrrawal by up to six new municipal wells.

The study area (fir. 1), covers approximately 70 square miles in southern Franklin County and a small part of northern Pickaway County in central Ohio. The modeled area (fig. 1) includes the southern part of the city of Columbus, Rickenbacker Air Force Base, and the communities of Obetz, Reese, Hamilton Meadows, and Shadeville. The Scioto River is the major stream in the area. Biq Walnut and Walnut Creeks are the principal tributaries to the Scioto.

This report is part of an overall study to model the flow and to describe the water-quality characteristics of the qlacial outwash aquifer. An earlier report by Weiss and Razem (1980) described the general. hydroqeology of the area and presented the theory and variables used in constructing the preliminary steady-state model. The steady-state model was used as a steppingstone in refining and calibrating the transient-state model presented in the report. A subsequent report will describe the around-water-quality characteristics in this study area.

\section{DESCRIPTION OF THE MODEL}

A finite-difference, two-dimensional ground-water flow model (Trescott and others, 1976) was used to simulate flow in the glacial outwash aguifer for both the transient-state calibration and the predictions of water-level changes due to pumping. Modifications to the program involved output variations that were helpful in interpreting intermediate steps and final results. These modifications are similar to those described in Razem and Bartholoma $(1980$, p. 16$)$. 


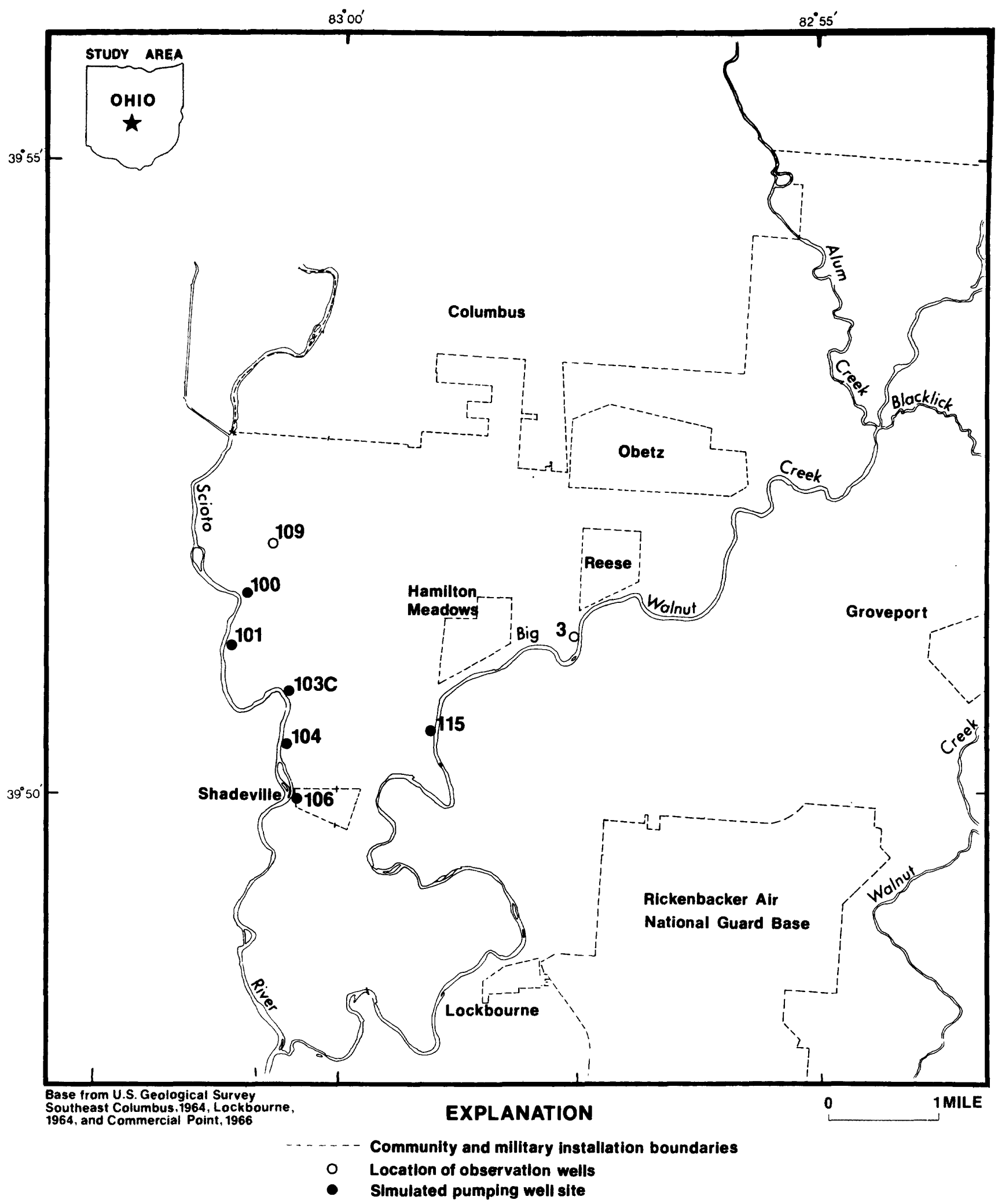

Figure 1.--Study area and well locations. 
Model Grid

A variable, block-centered grid (fig. 2) was used to simulate the flow in the glacial outwash. The grid used for the transient-state model consisted of 31 rows and 34 columns, which divided the area into 1,054 rectanqular blocks. At each node, or center point of each block, the finite-difference equation of ground-water flow is solved using hydrologic characteristics as input. The variahle grid spacing ranges from 313 to 10,039 feet with the smaller qrid spacing where wells are located or where the hydroloaic characteristics are better known.

\section{Hydrologic Characteristics}

The hydrolngic characteristics or data input at each node in the model were obtained from the earlier study by Weiss and Razem (1980), by additional data collected since that report, and by varyina values for the transient-state calibration until a visual best-fit was achieved. The characteristics (discussed below) include boundary conditions, recharge, aguifer properties, river and riverbed properties, and well discharqe.

\section{Boundary Conditions and Areal Recharge}

The boundary conditions used for this model are slightly modified from those described by Weiss and Razem (1980, p. 9). The constant-head boundary along the western edge is set to 720 feet, except for nodes 2 through 5 (fig. 2), which range from 690 to 715 feet. The constant head along the northern boundary has been modified to more closely match the more recent water-level measurements collected from 1977 to 1980 ; those constant heads ranqe from 685 to 725 feet. The eastern boundary is unchanged; the constant head is 730 feet between Blacklick Creek and Walnut Creek, and there is a no-flow boundary along the remainder. The entire southern boundary is a no-flow boundary.

Under these constant-head conditions, a flow of $37.2 \mathrm{ft} 3 / \mathrm{s}$ (cubic feet per second) across the western boundary and a total flow of $49.5 \mathrm{ft} 3 / \mathrm{s}$ across all boundaries was derived from the steady-state simulation. This is very close to the total flow that was estimated by Weiss and $\operatorname{Razem}(1980, \mathrm{p} .11)$. 


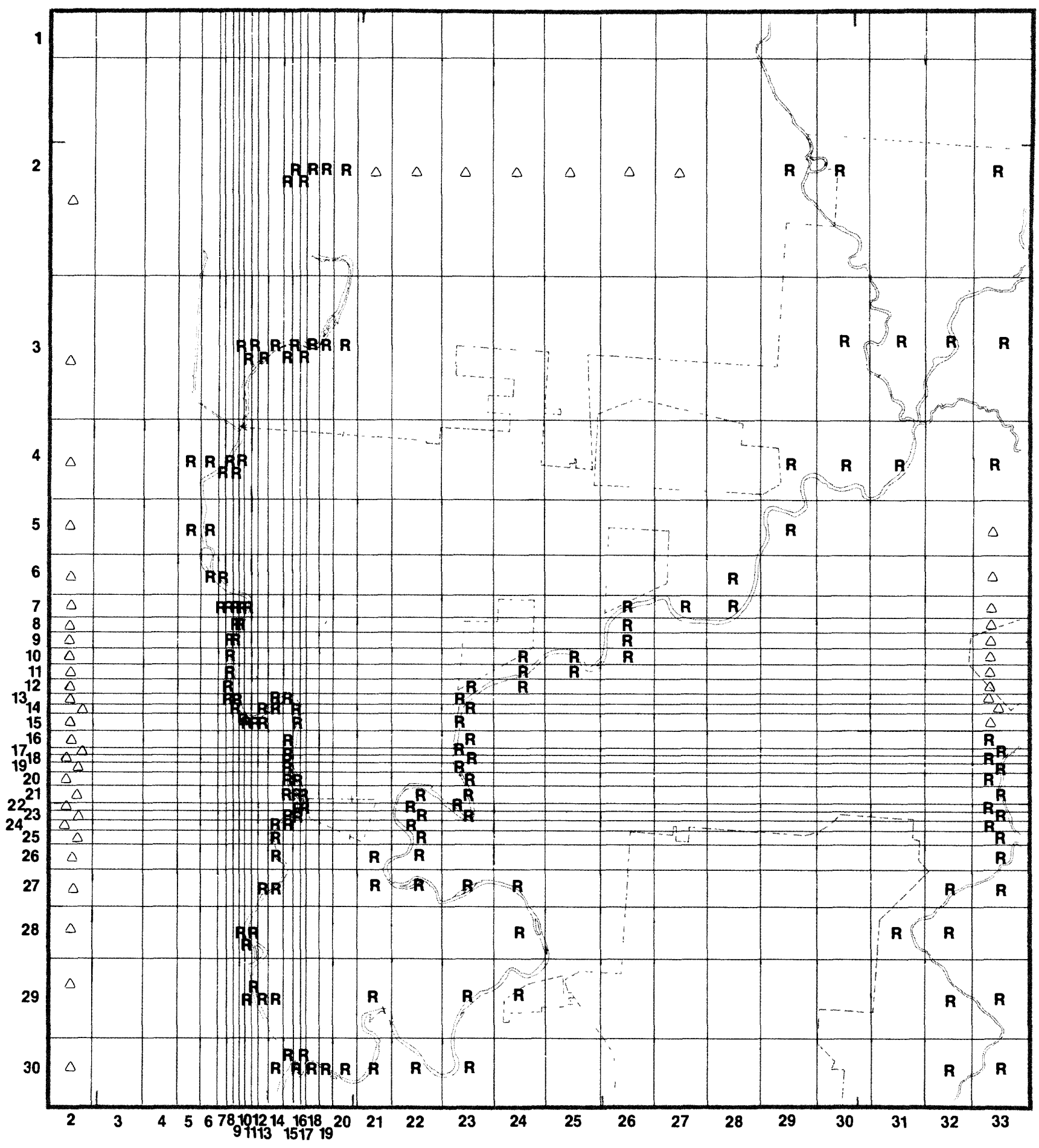

Figure 2.--Finite-difference grid and boundary conditions used in the modeled study area ( $\triangle=$ constant-head node, $R=$ river node). 
For the steady-state model, areal recharqe from precipitation was estimated to be 12 inches a year by hydroqraph analysis (Weiss and Razem, 1980, p. 10). The same hydrograph analysis, which determines recharge by multiplying the sum of water-level rises by the specific yield (0.1), was used to estimate areal recharge for each of the 12 pumping periods simulated in the transient-state condition (table 1$)$. The recharqe from precipitation for these periods ranged from 0 to 8.64 inches.

An averaqe recharqe of 12 inches a year was used for the predictive simulations. This may cause some discrepancies between the observed and predicted drawdowns during extended wet or dry periods.

\section{Aquifer Properties}

The hydraulic conductivity, saturated thickness, and specific yield that were used in this model are described by Weiss and Razem (1980). Additional data collected since that report have allowed some of the aquifer-property variables to be modified and refined.

The hydraulic conductivities that produced the best calibration in this report were those equal to the "K-map" described in weiss and Razem (1980, p. 8). The hydraulic conductivity is $400 \mathrm{ft} / \mathrm{d}$ (feet per cay) in the hiqhly permeable areas near the well sites. It is $40 \mathrm{ft} / \mathrm{d}$ in the low-permeable areas along parts of the northern and western boundaries and in an area south of well $115 \mathrm{~A}$ and east of well 103C. The hydraulic conductivity is $200 \mathrm{ft} / \mathrm{d}$ over the remaining area.

The bedrock altitude, which has been modeled as an impermeable boundary, was obtained from well logs and a bedrock altitude map (Schmidt, 1958). The annual water-level changes since 1976 in the study area have been small; therefore, the saturated aquifer thickness has remained essentialy unchanged.

The specific yield of 0.1 (Weiss and Razem, 1980, p. 10) is an estimate that has proved satisfactory during the transient-state calibration. It was also used for the predictive simulations. 


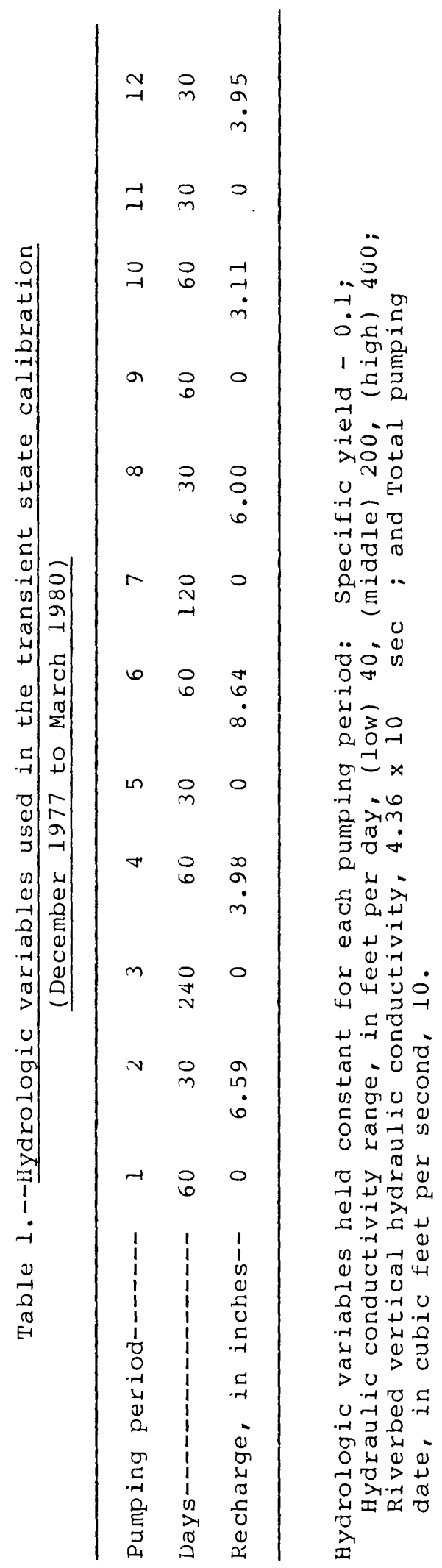


River elevations were obtained from U.S. Geological Survey 7 1/2-minute topographic maps; a linear interpolation was used between contours. A river depth of 5 feet was used for all parts of the river for all transient simulations.

The average riverbed vertical hydraulic conductivity of $4.36 \mathrm{x} 10-6 \mathrm{ft} / \mathrm{s}$ (feet per second) is the same as that used in the preliminary model of the study area (Weiss and Razem, 1980, p. 13). Leakage to each river block or cell has been adjusted to account for streambed areas that are smaller than their representative blocks.

During steady-state simulation, the Scioto River and Big walnut Creek combined gain a net of $100 \mathrm{ft} 3 / \mathrm{s}$, which compares to a 95-percent duration flow of $139 \mathrm{ft} 3 / \mathrm{s}$ for the Scioto River at Columbus and Big Walnut Creek at Reese.

\section{Well Discharge}

The well discharge in the modeled area for transient-state calibration was $10 \mathrm{ft} 3 / \mathrm{s}$ for each pumping period (table 1 ). The total pumping rates were modified from the earlier study (Weiss and Razem, $1980, p$. 14) to account for user variation and pumping at a nearby quarry.

\section{TRANSIENT-STATE MODEL CALIBRATION}

The purpose of calibrating the model is to simulate observed ground-water conditions until a best-fit condition is obtained by adjusting variables within hydrologically reasonable ranges. Simulations of future water-level changes probably are reliable, especially within the range of conditions simulated to attain a best-fit condition.

In the preliminary steady-state calibration (weiss and Razem, 1980), the model was adjusted until it satisfactorily reproduced the potentiometric surface interpreted from water levels measured in December 1977. The more definitive transient-state model calibration was made by simulating water-level changes from December 1977 to March 1980 and comparing them to measured water-level changes in observation wells for the same period. 
The calibration period of December 1977 to March 1980 was divided into 12 pumpina periods based on available water-level data and precipitation patterns. The starting heads used for the first pumping period were the final heads produced by the steady-state model. The comparison of observed water-level. changes and computed water-level changes (fig. 3) appears to he good for both well 3 and well 109. (See fiq. 1 for well. locations.)

The only variable stress applied to the ground-water system during the transient-state calibration was recharge from precipitation. Well discharge in the model was not varied during the transient calibration because pumpage rates were assumed to be constant. Therefore, stresses imposed on the simulated aquifer during transient calibration were small compared to the pumping stress applied during the predictive simulations. This may cause unforeseen discrepancies between the predictions and future observations.

\section{SIMULATED AQUIFER RESPONSE TO FUTURE PUMPING}

Future pumping was simulated from wells 100, 101, 103C, 104, 106, and 115A (fig. l), in addition to existing wells simulated in the transient calibration. Discharge from existing wells was assumed to remain constant at a combined total of $10 \mathrm{ft} / \mathrm{s}$. Althouqh this discharge may fluctuate slightly, it is not anticipated that any significant change will take place. Simulations, were made for combined anticipated well discharges of $48 \mathrm{ft}^{3} / \mathrm{s}, 70 \mathrm{ft} / \mathrm{s}$, and $94 \mathrm{ft} 3 / \mathrm{s}$ for $30-y e a r$ periods.

The following results show predicted water-level changes from the March 1980 computer-generated levels. Areal recharqe was kept constant, 12 inches per year, for all time periods in all predictive simulations. 


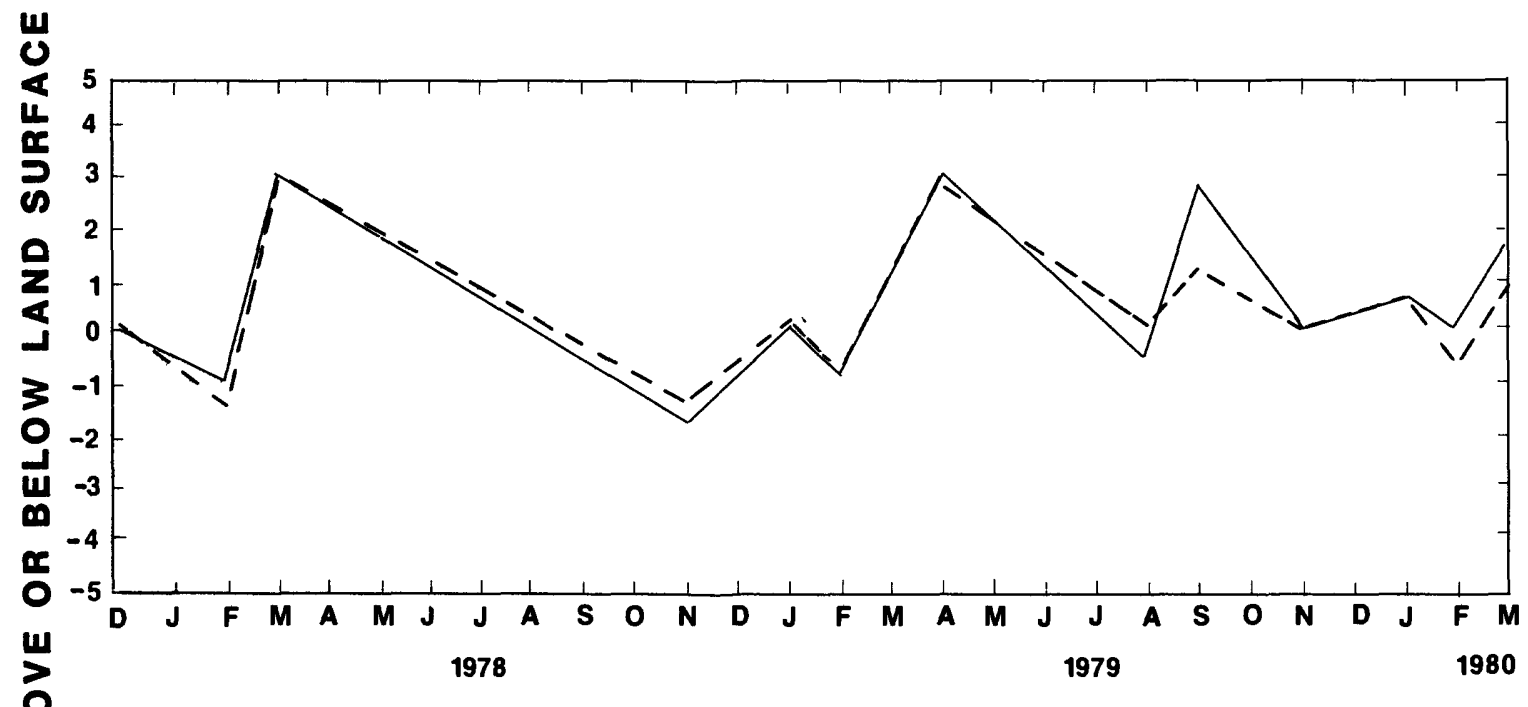

WELL 3

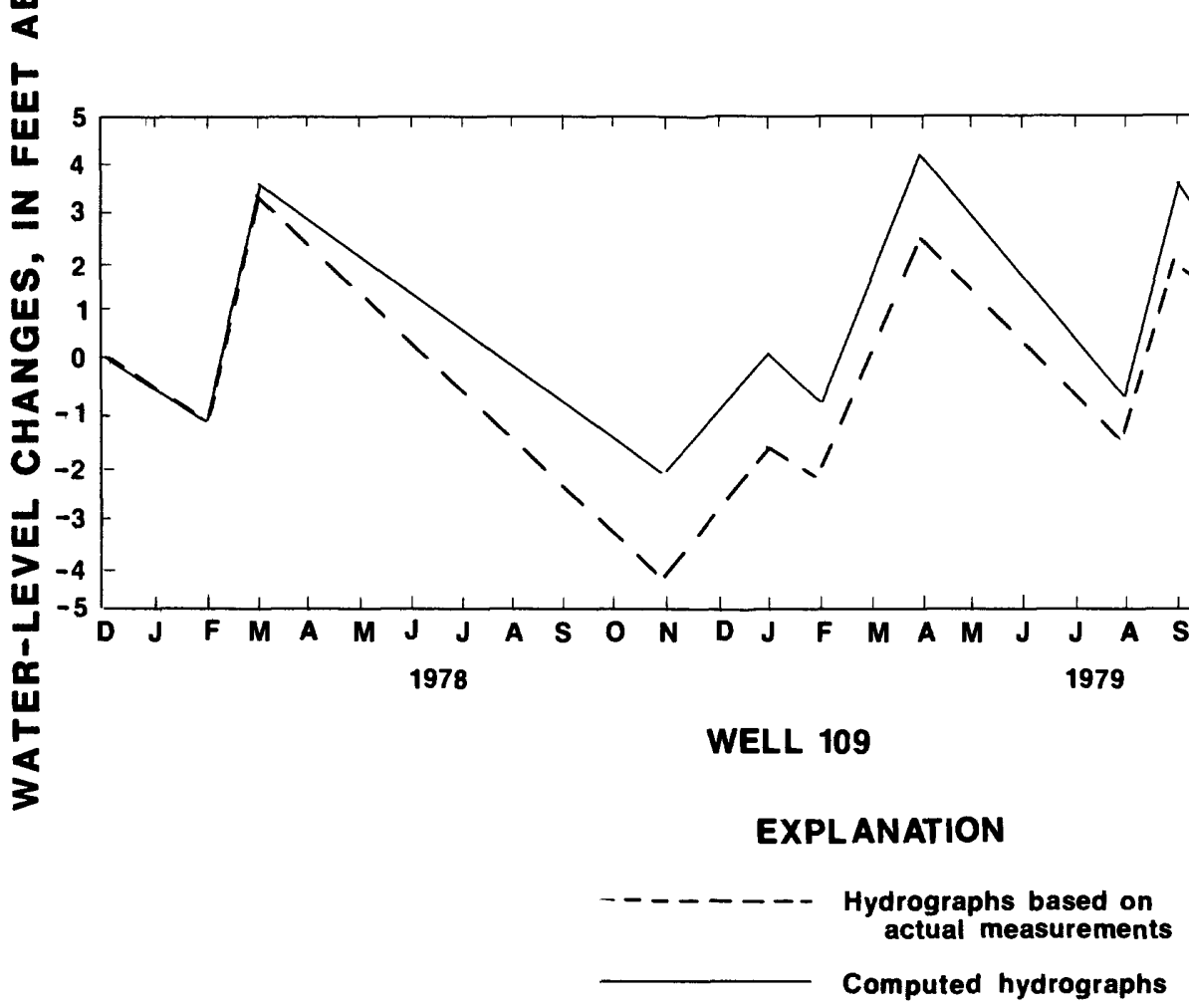

Figure 3.--Comparison of observed and computed water-ievei changes at wells 3 and 109 from December 1977 to March 1980. 


\section{Case I}

In the first predictive simulation, pumpage from wells was $48 \mathrm{ft} 3 / \mathrm{s}$, of which $38 \mathrm{ft} 3 / \mathrm{s}$ was discharged from four of the new wells (table 2). Water-level declines were generally 10 to 15 feet in the area of the four wells. Declines of 5 to 10 feet developed as much as 2 miles away (fig. 4). Water levels declined to 26 feet at well $103 \mathrm{C}$ and from 15 to 20 feet at wells 101,104 , and 115A.

Net leakaqe from the aquifer to the stream was reduced from $100 \mathrm{ft}^{3} / \mathrm{s}$ before pumping to $64, \mathrm{ft}^{3} / \mathrm{s}$ when pumping at a rate of $48 \mathrm{ft}^{3} / \mathrm{s}$. The decrease of $36 \mathrm{ft}^{3} / \mathrm{s}$ represents an increase of $11 \mathrm{ft} 3 / \mathrm{s}$ from the stream to the aquifer and an interception of $25 \mathrm{ft}^{3} / \mathrm{s}$ that would have flowed from the aquifer to the stream had there been no pumping. Flow from constant-head boundaries increased by less than $2 \mathrm{ft} 3 / \mathrm{s}$. Of the $38-\mathrm{ft}^{3} / \mathrm{s}$ increase in pumping attributed to wells $101,103 \mathrm{C}, 104$, and $115 \mathrm{~A}, 28$ percent comes as infiltration from the streams, 65 percent comes as intercepted flow, and the remaining 7 percent comes from an increase in constant-head flow and storaqe.

\section{Case II}

In the second predictive simulation, pumpage from wells was increased to $70 \mathrm{ft} 3 / \mathrm{s}$, of which $60 \mathrm{ft} 3 / \mathrm{s}$ was discharged from four of the new wells (table 2). Water-level declines were generally 20 to 30 feet in the vicinity of the four wells, 10 to 20 feet about 1 mile away, and greater than 5 feet at 3 miles from well $103 \mathrm{C}$ (fig. 5). Water levels declined as much as 57 feet at well $103 \mathrm{C}$ and from 20 to 35 feet at wells 101 , 104, and 115A. Steady-state conditions were reached after 12 years of pumping.

Net leakaqe from the aquifer to the stream was reduced from $100 \mathrm{ft} 3 / \mathrm{s}$ in the prepumping condition to $44 \mathrm{ft} 3 / \mathrm{s}$ during pumping. The decrease of $56 \mathrm{ft} 3 / \mathrm{s}$ represents an increase of $20 \mathrm{ft} 3 / \mathrm{s}$ from infiltration from the river and an interception of $36 \mathrm{ft} 3 / \mathrm{s}$ that would have flowed from the aquifer to the stream had there been no pumping. Flow from constant-head boundaries increased by sliqhtly more than $3 \mathrm{ft} 3 / \mathrm{s}$. Of the $60-\mathrm{ft} 3 / \mathrm{s}$ increase in pumping attributed to wells $101,103 \mathrm{C}, 104$, and 115A, 33 percent comes as infiltration from rivers, 60 percent from intercepted flow, and the remaining 7 percent from an increase in constant-head flow and initial storage. 


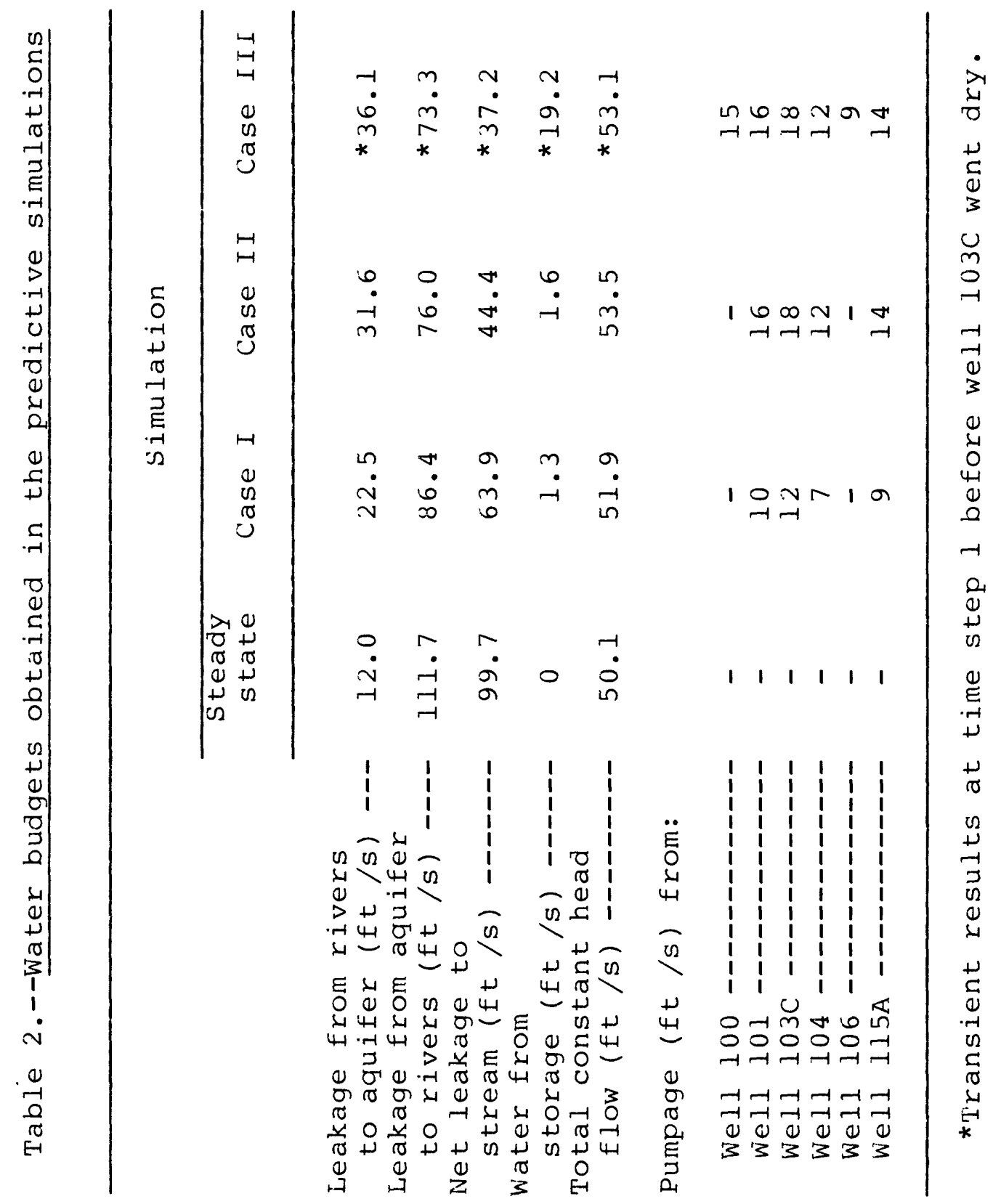




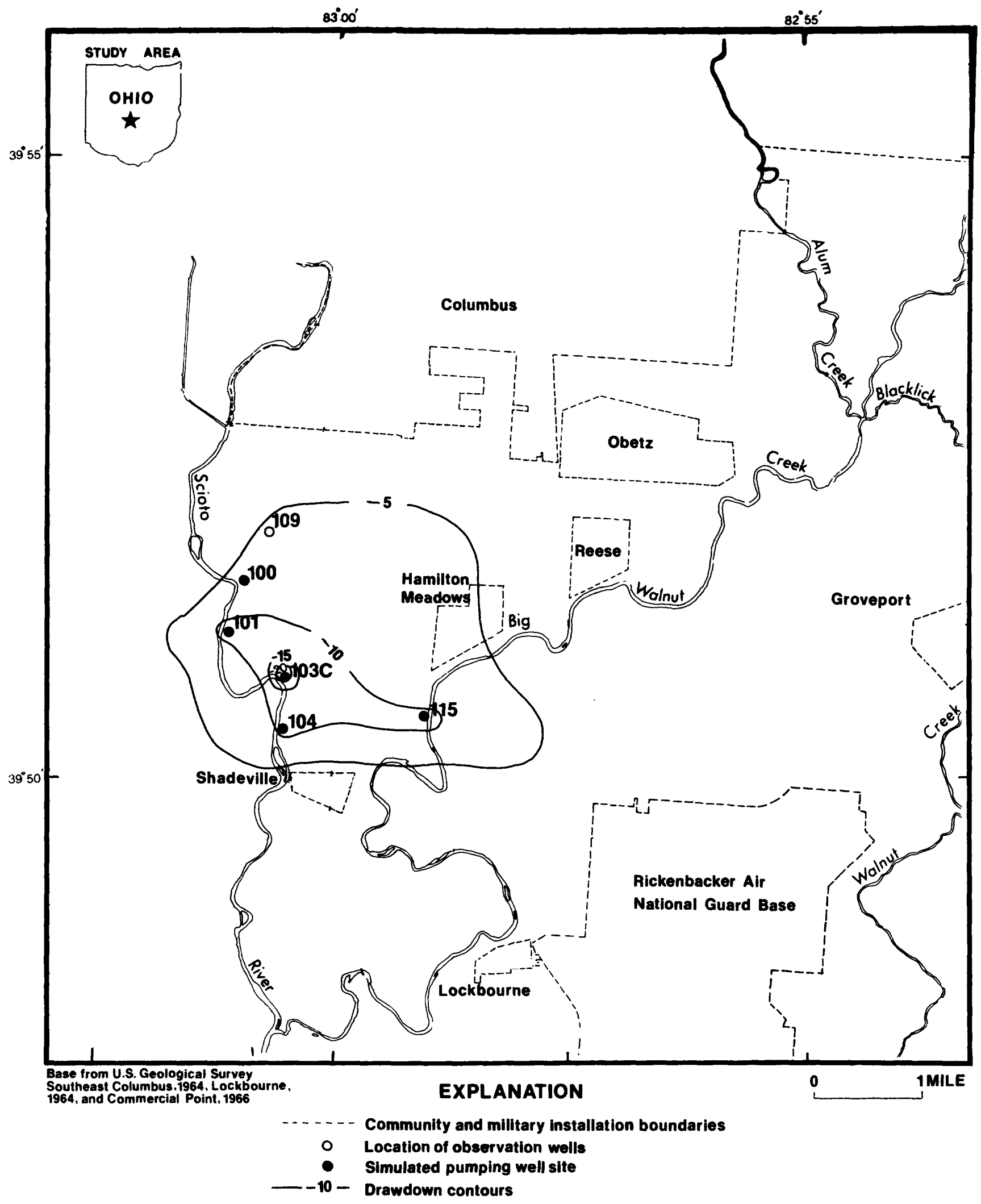

Figure 4.--Predicted drawdowns after combined pumping of $48 \mathrm{ft} 3 / 8$ for 12 years. 


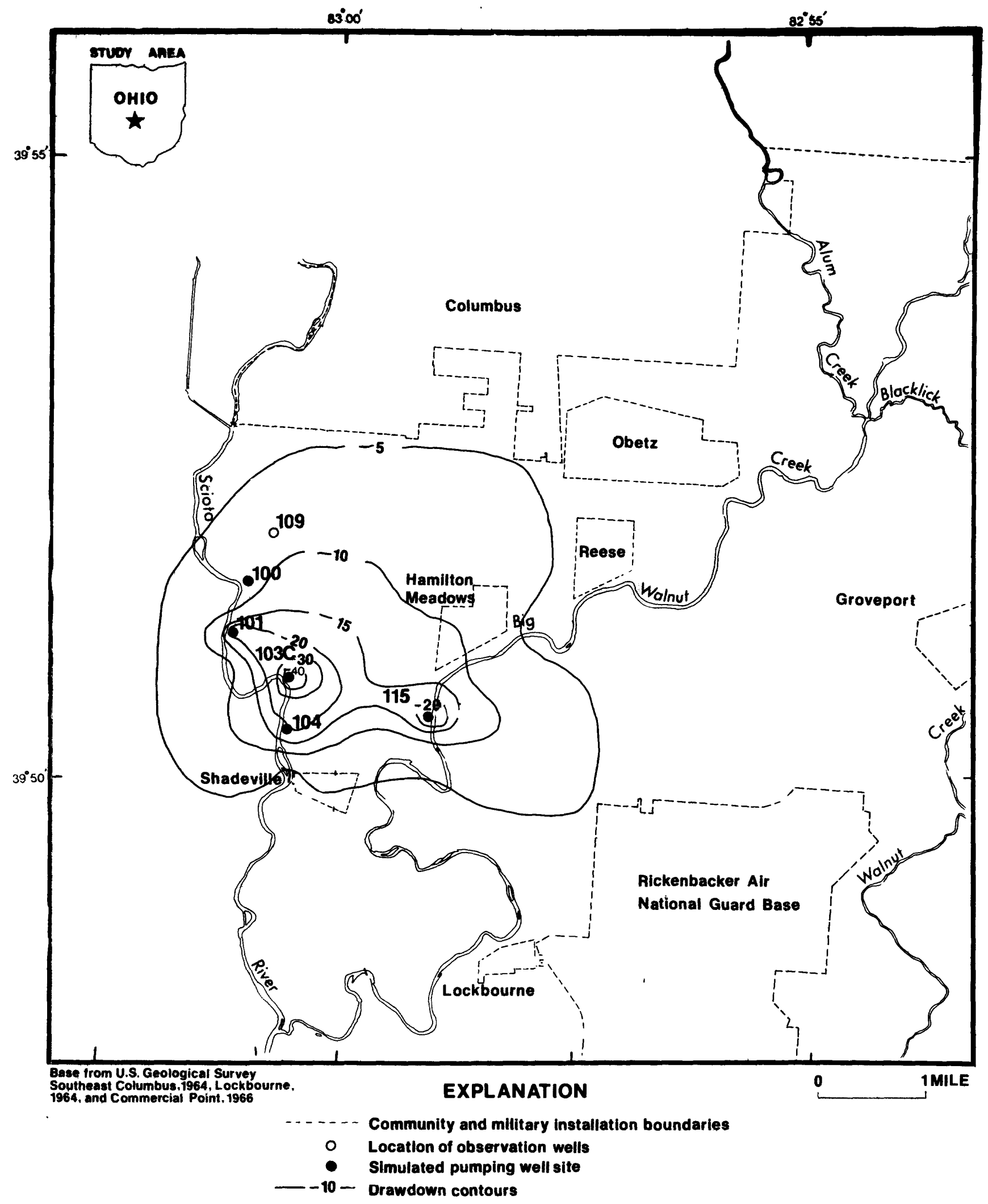

Figure 5.--Predicted drawdowns after combined pumping of $70 \mathrm{ft}^{3 / 3}$ for twelve years. 


\section{Case III}

In the third predictive simulation, pumpage from wells was $94 \mathrm{ft}^{3} / \mathrm{s}$, of which $84 \mathrm{ft} 3 / \mathrm{s}$ was discharqed from all six new wells (table 2). This simulation was stopped after well $103 \mathrm{C}$ went तry during the first year of pumping. The configuration of the drawdown map at the time well 103C went dry (fig. 6) is similar to that shown in figures 4 and 5, except for the much steeper gradient near well $103 \mathrm{C}$.

At the time step before the well went dry, approximately 30 percent of the pumpage was infiltration through the riverbed, 45 percent was intercepted flow, 22 percent was from storage, and the remaining 3 percent was from increased constant-head flow.

\section{SUMMARY}

A transient-state digital-computer model was constructed that' simulates flow conditions in a glacial outwash aquifer in part of the Scioto River basin. The model is based on a variable, block-centered, finite-difference grid of 31 rows and 34 columns. Constant-head and no-flow boundaries were used along the model perimeter. Uniform recharge from precipitation, 12 inches per year, was applied areally. A variable hydraulic conductivity distribution having an intermediate value of 200 $\mathrm{ft} / \mathrm{d}$ and a uniform specific yield of 0.1 was used. Vertical hydraulic conductivity of the riverbed, between the river and the aquifer, was uniform at $4.36 \times 10^{-6} \mathrm{ft} / \mathrm{s}$.

The transient model, which was based on an earlier steady-state model, was used for estimating future water-level changes that might result from pumping. The model was calibrated by matching observed water-level changes with simulated water-level chanqes until a visual best-fit condition was reached. 


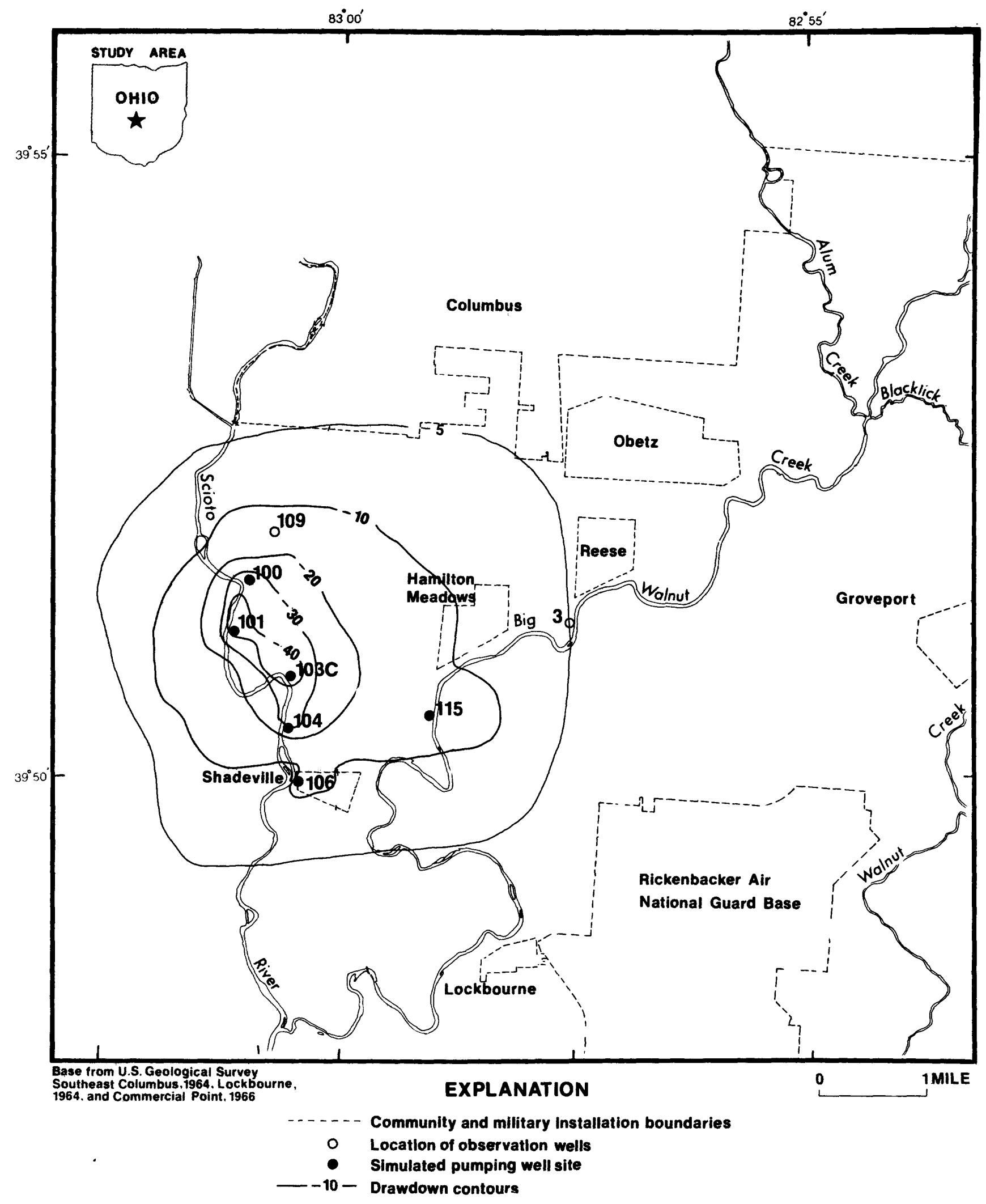

Figure 6.--Predicted drawdowns at time $103 \mathrm{C}$ goes dry after combined pumping of $94 \mathrm{ft} 3 / \mathrm{s}$. 
The well discharge in the modeled area for transient-state calibration was $10 \mathrm{ft} / \mathrm{s}$ for each pumping period. The results of the model indicate that pumping four new production wells at a rate of $38 \mathrm{ft} 3 / \mathrm{s}$ (a combined rate of $48 \mathrm{ft} / \mathrm{s}$ ) would lower the water level 10 to 15 feet in the area of the wells. Infiltration through the riverbed would account for 28 percent of the pumpage. Pumping four new production wells at the rate of $60 \mathrm{ft} / \mathrm{s}$ (a combined rate of $70 \mathrm{ft} 3 / \mathrm{s}$ ), would cause water levels to decline 20 to 30 feet in the area of the wells; infiltration through the riverbed would account for 33 percent of the pumpage. If all six new production wells were put into production at $84 \mathrm{ft} 3 / \mathrm{s}$ (a combined rate of $94 \mathrm{ft} 3 / \mathrm{s}$ ), one of the wells (103C) would go dry before 1 year of pumping time.

\section{REFERENCES}

Razem, A. C., and Bartholoma, S. D., 1980, Diqital-computer model of qround-water flow in Tonele Valley, Utah: U.S. Geological Survey Open-File Report 80-446, $55 \mathrm{p}$.

Schmidt, J. J., 1958, The ground water resources of Franklin County, Ohio: Ohio Department of Natural Resources, Division of water Bulletin $30,97 \mathrm{p}$.

Trescott, P. C., Pinder, G. F., and Larson, S. P., 1976, Finite-difference model, for aquifer simulation in two dimensions with results of numerical experiments: U.S. Geological Survey Techniques of Water Resources Investiqations Book 7, Chapter Cl, $116 \mathrm{p}$.

Weiss, E. J., and Razem, A. C., 1980, A model for flow through a qlacial nutwash aquifer in southeast Franklin County, Ohio: U.S. Geological Survey Water-Resources Investigations 80-56, $27 \mathrm{p}$. 